\title{
Is Vulnerability Factors Discourages Women- Empowerment? The moderating role of Environmental, Health, Economic and Political Vulnerability between Microfinance Institutions and Women-Empowerment
}

Waseem Ul Hameed ( $\nabla$ expert_waseem@yahoo.com )

Research article

Keywords: Health vulnerability, environmental vulnerability, microfinance, women empowerment, microcredit, micro-saving, micro-insurance.

Posted Date: November 27th, 2019

DOI: https://doi.org/10.21203/rs.2.17774/v1

License: (c) (i) This work is licensed under a Creative Commons Attribution 4.0 International License. Read Full License 


\section{Abstract}

Background Women-empowerment is still a problematic area in most of the developing countries including Pakistan. The women contribution is limited and not well acknowledged in various developing countries. As the women contribution in Pakistani economy is only $25-30 \%$ which is quite low as compared to most of the developing as well as developed countries. Various studies addressed the women-empowerment; however, literature is missing to consider the role of various vulnerability factors such as health, environment, economic/social and political. Microfinance institutes are working; however, the result is limited. It is due to the various vulnerability factors which effect negatively on women empowerment and decreases the positive role of microfinance institutes. Therefore, the prime objective of this study is to examine the role of vulnerability factors and microfinance institutes in womenempowerment.Methods Cross-sectional research design was selected, and survey was carried out to collect the data from female clients of microfinance institutes. Primary data were analyzed by using Partial Least Square-Structural Equation Modeling (PLS-SEM).Results Findings of the study revealed that vulnerability factors such as women health, environment, economic/social conditions and political conditions decrease women-empowerment. However, microfinance institutes are most significant to enhance women-empowerment. Services of microfinance institutes such as micro-credit, micro-saving and micro-insurance has significant positive relationship with women-empowerment.Conclusion Various vulnerability factors such as women health vulnerability, environment vulnerability, economic/social vulnerability and political vulnerability should be managed to increase women-empowerment. Microfinance institutes is one of the solutions to handle these vulnerabilities through various services. Therefore, the current study is significant for microfinance institutes, state bank of Pakistan and government of Pakistan while making the strategies to enhance women-empowerment.

\section{Background}

Women-empowerment (WE) is a key part of every nation's success. As women are the integral part of every society $(1,2)$. WE is most valuable for economic development of families and communities (3). It is most crucial for the growth and development of country (1). However, phenomenon of WE seem not to be well acknowledged in most of the developing countries, particularly in Pakistan. Therefore, the contribution of women in Gross Domestic Product (GDP) and economy is limited. Consequently, WE is still a problematic area in various developing countries comprising Pakistan. Women contribution in GDP and nation's economic growth is recorded with an incomparable level in most of the developed and developing countries such as United States (US), United Kingdom (UK), Indonesia and Malaysia. For instance, women contribution in US is recorded $23-98 \%$ in the GDP and USD \$3 trillion contribution in economy through participation in micro-enterprise (4). In case of UK, women contribution is $50 \%$ to annual GDP and $54.1 \%$ of total employment, in Indonesia, women contribution is $55 \%$ in GDP and $75 \%$ contributed in employment opportunities, in Malaysia, 44\% in GDP and 56\% in employment opportunities through micro-enterprises $(2,5,6)$. These figures show that the women contribution is most important for the success of nation's economy. 
However, the women contribution is limited and not well acknowledged in most of the developing countries such as Pakistan. As the women contribution in Pakistan economy is only $25-30 \%$ (7). This contribution is very low as compared to the other countries as mentioned above. It indicates that the WE is still a problematic area in Pakistan. Government of Pakistan failed to empower women from past 63 years (8). This is one of crucial problem of low economic growth of Pakistan. To resolve this issue many microfinance institutes are working, however, the result is limited. It is due to the various vulnerability factors which effect negatively on WE and decreases the positive role of microfinance institutes. Health vulnerability is one of the important factors which effect any individual (9), therefore, it may also decrease WE. Moreover, environment which include climate change as well as disaster has the ability to effect on individuals by decreasing livelihood opportunities (10). Along with these factors, economic and political vulnerability also has equally important $(11,12)$ which can affect WE. These are the most important factors which are responsible of low WE in Pakistan, however, these are not addressed by scholars in the context of WE. Thus, this is one of the motivational factors of the study.

Microfinance provides various financial services to reduce poverty and empower its beneficiaries. It is an idea through which low-income people acquire financial services and enable themselves sufficient to get rid from poverty (13). Financial services comprise micro-credit, micro-saving as well as micro-insurance. Microfinance institutes has positive influence on WE and poverty alleviation (1,14-16). Therefore, microfinance factors have significant relationship with WE. From two decades, microfinance institutes have emerged into an important global industry and it is fastest rising industries in whole world (17-20). Many microfinance institutes are advocating WE; however, the women population is living in vulnerable condition (21). As in Pakistan, 3,130 microfinance units are working with gross loan portfolio PKR 108,881 million and covering 99 districts of Pakistan (22). Additionally, the participation of women is increasing, and it is more than men.

Thus, an important question is raised. Why the WE is not achieved in Pakistan? Even, many microfinance institutes are working, and women participation is increasing day by day (22). Most of the microfinance institutes are especially focusing on women's advancement. Hence, low WE is based on some responsible factors. Particularly vulnerabilities which are based on health vulnerability, environmental vulnerability, political vulnerability and economic vulnerability $(12,23)$. These vulnerabilities decrease the positive influence of microfinance institutes towards WE. Hence, the current study has two prime objectives:

1. To examine the effect of microfinance factors on WE. This objective leads three sub objectives:

1.1 To study the influence of micro-credit on WE.

1.2 To study the influence of micro-saving on WE.

1.3 To study the influence of micro-insurance on WE.

2. To examine the moderating role of vulnerabilities on the relationship of microfinance factors and WE. 
The current study focused on the Southern Punjab Pakistan. As this area is related to the high poverty areas of Pakistan (24) and more research is required on WE in this area (8). In Bahawalpur (a part of Southern Punjab) poverty falls from $69.64 \%$ to $55 \%$. Moreover, this area consists of two parts. One part consists of desert and other part consists of nearby rivers which threatens women micro-enterprises. Hence, the vulnerabilities are more in this area which are the responsible factors of low WE.

This study is important because it has key contribution to the literature by highlighting various vulnerability factors. This study highlighted that health vulnerability, environmental vulnerability, political vulnerability and economic vulnerability are those factors which are responsible of low WE. The conceptual framework of the current study was drawn based on empirical evidence as well as theoretical gaps identified in the prior literature. The support and explanation for the framework were drawn from two theoretical perspectives, i.e. Mayoux's Feminist Empowerment Theory and Relational Theory of Risk. In present study, the vulnerability was incorporated as a moderating variable to understand better as well as explain the relationship between microfinance factors and WE. According to the Mayoux's Feminist Empowerment Theory, microfinance increases the WE. However, from the results of the current study, in the areas like Southern Punjab, Pakistan, where the vulnerability factors exist, the theory fails to justify this statement. As in these areas, microfinance is not beneficial to reduce poverty and enhance WE. Therefore, vulnerability could be service as one of the limitations of the Mayoux's Feminist Empowerment Theory. Thus, this study contributed by findings the limitation of Mayoux's Feminist Empowerment Theory through examining moderating role of vulnerability.

Literature Review

\subsection{Women-Empowerment (WE)}

WE is one of the process of preparing women to be economically self-determining, self-reliant, and having higher positive esteem that enables women to face any challenging situation as well as to contribute to various development activities (25). In this process women get more control over the different resources, human and control over intellectual resources involves information, knowledge, idea, financial resources such as money and control on decision making power at household level, community level, nation level and gain more power (26). Microfinance institutes are trying to enhance WE by their services such as micro-credit, micro-saving and micro-insurance. Because microfinance has been considered to be a useful tool to alleviation the poverty and enhance WE (27). As the microfinance services have significant positive relationship with WE.

\subsection{Vulnerability}

Scholars and practitioners define vulnerability in different ways (28). It can be described as the "probability of risk today of being in poverty or to fall into deeper poverty" (World Bank, 2012). As cited by (29): "it involves a combination of factors that determine the degree to which someone's life and livelihood are put at risk by a discrete and identifiable event in nature or society". It is a probability of experiencing future loss in welfare, and a family becoming poor or continuing to be poorer if living in 
poverty $(30,31)$. The concept of vulnerability entails how communities respond and adapt to social, environmental and economic changes $(32,33)$. It is a higher degree of experience to shocks, risks as well as proneness of food uncertainty that can challenge the household's existence (34).

Literature highlighted different dimensions of vulnerability because it varies from region to region. Banerjee and Jackson (23) described that, vulnerability is based on three dimensions; social, economic and environmental vulnerability. Social vulnerability consists of solidarity circles and social relations. A strong social relationship enables poor people to defend themselves better against vulnerability (35). Solidarity circles entail friends and family, which are the fundamental assets that help in dealing with poverty. Environmental vulnerability consists of climate change and natural disasters including floods, cyclones and river erosion (23). Due to the changes in the economy such as recession and failure in micro-enterprise, people are exposed to vulnerability. In these conditions, poor people lose their capability to repay the loan. According to previous studies $(36,37)$, the place is one of the major determinants of vulnerability. Place and environmental vulnerability consist of natural disasters including earthquakes, flood, excessive rainfall, shortage of water, windstorms and food scarcity. There are also other dimensions of vulnerability such as health which include the breakup of families, the death of an employed member, loss of farming skills and increase in the presence of fatal diseases $(36,37)$. Women living in poverty are also facing various vulnerabilities such as political injustices which decreases the WE (12).

\subsection{Mayoux's Feminist Empowerment Theory}

The Mayoux (38) feminist theory is one of the prominent theories to discuss WE. This theory focuses on women social and economic empowerment, particularly in developing countries (39). The core idea to focus women is that, a higher level of women poverty (39). As the $70 \%$ poverty belongs to poverty worldwide (Kabeer, 2012). This theory is one of the entry points of microfinance to WE. According to framework of Mayoux (39), provision of opportunities to women such as credit and saving encourages the decision-making power. Women invest credit into micro-enterprises which generate income and income increases the economic empowerment among women. It also enhances social empowerment by increasing the decision-making ability of women. It increases the social capital by enhancing the network. It focusses on poor women and women who can play a role for change (40). This theory focuses on equity and equality among men and women. As the decrease in gender discrimination leads to enhance women social and economic empowerment. Finally, this theory tries to enhance WE by using microfinance factors. Framework of Mayoux's Feminist Empowerment Theory is highlighted in Figure 1 which shows that services of microfinance institutes have the ability to increase WE by reducing the poverty level.

[Insert Figure 1 Here] 
This is the underpinning theory which explains the vulnerability effect on WE. Relational theory of risk is primarily based on three major fundamentals: "an object at risk, a risk object, and a relationship of risk" (41). These three variables are interlinking with each other's which explains the effect of one object on another object.

An object at risk is based on any object containing value which is at stake due to the risk object. Risk object is based on an entity that threatens the object at risk. It is an object consists of different identity traits pertaining to danger and harm. These risks may involve hazards such as any environmental change, health issues, social issues such as discrimination among men and women, low income level and political issues. As vulnerability involves different hazards such as natural disasters, climate changes, physical hazards, economic problem of women, social problems, political issues and any other dangerous objects $(12,23,36,37)$. The connection between risk object and an object at risk is known as the third element of this theory which is relationship of risk. In the current study, vulnerability is considered to be a risk object, WE is considered as an object at risk and the relationship of these two is the third element of this theory. Additionally, the relationship of microfinance factors (micro-credit, microsaving, micro-insurance) and WE is a valuable relationship, hence, this relationship is also considered as an object. The value of this relationship is at stake due to vulnerability. The equation of this theory is given below.

[Insert Figure 2 Here]

\subsection{Hypothesis Development}

\subsubsection{Micro-Credit, Women-Empowerment and Vulnerability}

Microcredit is one of the important microfinance services which offers small loan to improve existing small-scale business of poor people or establish a new one (42). It is a provision of cash and a smaller amount of loan to self-employed people to improve their small business (43). It improves women income and also increase the decision-making power (25). Microfinance institutes provide credit to poor women and these women invest this credit in micro-enterprises which generate income and enhance decision making power. Therefore, micro-credit has positive role to enhance social as well as economic empowerment of women community. According to Al-Shami, Razali (14), credit enhance WE by decreasing the issue of gender equality. 
Moreover, according to Zoynul and Fahmida (44), micro-credit enhances the social and women economic empowerment. On the other hand, Atmadja, Su (45) found that financial capital has negative impact on women micro-enterprise. As the micro-enterprise generate income and enhance empowerment, in case of negative impact it decreases the income which leads to decrease in WE. Additionally, micro-credit is not a good indicator of empowerment Garikipati (46). Hence, sometimes micro-credit shows negative, less effect or not effect at all. It is due to the vulnerabilities which effect the women micro-enterprises adversely. Vulnerability "involves a combination of factors that determine the degree to which someone's life and livelihood are put at risk by a discrete and identifiable event in nature or society" (29). Particularly in Southern Punjab Pakistan, vulnerabilities are linked with desert, nearby rivers, social problems and political issues. Deserts consists of wing storms, water and food scarcity, less rainfall and different diseases. Social vulnerability includes health issues, single earning hand, physical disability and discrimination. On the other hand, in other part of this area, nearby rivers cause flood in rainy season which effect agriculture area and other women micro-enterprises. This area is also politically vulnerable. Thus, in this area, vulnerabilities disturb the income generating activities of poor women which effect negatively on WE and microfinance services. Thus, it is proposed that:

$\mathrm{H}_{1}$ : Micro-credit has a significant relationship with WE

$\mathrm{H}_{2}: \quad$ Vulnerability moderates the relationship between micro-credit and WE

\subsubsection{Micro-Saving, Women-Empowerment and Vulnerability}

Micro-saving based on saving accounts which increases the saving (47). It is one of the microfinance services which enables people to save their assets with the help of weekly saving and also to contribute in group saving (48). Microfinance institutes provides the opportunity of individual and group saving. Micro-saving enhances the productivity of rural women (49). As saving is one of the microfinance services which has long lasting effect on women (50). According to Bernard, Kevin (51), saving has positive impact on women microenterprise. Therefore, it enhances the income from microenterprise which automatically boost up WE. Nevertheless, micro-saving promotes WE (52) and help people to resolve their health emergencies (50). On the other hand, as discussed above, financial capital which is also include savings have negative impact on women micro-enterprises (45). This negative effect is due to the vulnerabilities which reduces the positive influence of microfinance institutes on women. Poor women utilize their savings to mitigate the effect of vulnerabilities and could not invest in income generating activities. Therefore, vulnerabilities moderate the relationship between micro-saving and WE. Therefore, following hypotheses are proposed:

$\mathrm{H}_{3}$ : Micro-saving has a significant relationship with WE

$\mathrm{H}_{4}$ : $\quad$ Vulnerability moderates the relationship between micro-saving and WE

\subsubsection{Micro-Insurance, Women-Empowerment and Vulnerability}


Micro-insurance is the safety of people having poor economic condition against hazards in exchange for systematic premium payments equivalent to likelihood which involves a cost of risk (53). Microfinance institutes provide various financial services including business insurance facility to help poor people in a vulnerable economic situation for protection. It makes them capable of purchasing assets and these facilities frequently ignored by the commercial banks (54). Poor people manage shocks by using various strategies including formal group based and self-insurance (55). These shocks include vulnerabilities such as health, floods, water scarcity, wind storms, any other natural disaster, social, economic political issues. However, use of finance to mitigate vulnerabilities restrict women to capitalize in various income earning activities which reduces the positive contribution of insurance to enhance WE. Vulnerabilities destroys the micro-enterprises of poor women and most of the women use insurance to mitigate the effect of vulnerabilities. Hence, micro-insurance is one of the tools to enhance WE. However, vulnerabilities moderate this relationship as highlighted in below hypotheses;

$\mathrm{H}_{5}: \quad$ Micro-insurance has a significant relationship with WE.

$\mathrm{H}_{6}$ : Vulnerability moderates the relationship between micro-insurance and WE.

\section{Methods}

The current study is based on quantitative research based and using cross sectional design of research. A survey instrument was used to assemble the primary data from female clients of microfinance institutes in Southern Punjab, Pakistan.

\subsection{Population and Sampling}

This study is key to examine the connection between microfinance institutes and WE. Therefore, the population of the current study is the female clients of microfinance institutes which are involved in microfinance services. Area cluster sampling was preferred to collect the primary data. Additionally, the sampling is divided into four steps.

1.

Southern Punjab was divided into 10 clusters.

2.

05 clusters selected randomly ("Bahawalpur, Rahim Yar Khan, Muzaffargarh, Dera Ghazi Khan, Bahawalnagar").

3.

Specific number of questionnaires were distributed in each cluster which was determined by using below formula.

$\mathrm{nz}=(\mathrm{Nz} / \mathrm{N}) * \mathrm{n}$

Where, 
$\mathrm{nz}=$ required sample size for each cluster, $\mathrm{Nz}=$ total population of each cluster, $\mathrm{N}=$ total population size in all clusters, $\mathrm{n}=$ total sample size

Total female clients having involvement in various microfinance services including; credit, saving and insurance are 143,000 approximately. These female clients in selected clusters; Bahawalpur, Rahim Yar Khan, Muzaffargarh, Dera Ghazi Khan and Bahawalnagar are; 29500, 21000, 17000, 18500 and 14500, respectively (7). Moreover, this study distributed 500 questionnaires. Sample size for each selected cluster is calculated below;

Bahawalpur: $\mathrm{nz}=(29,500 / 100,500) * 500=147=29.4 \%$

Rahim Yar Khan: $n z=(21,000 / 100,500) * 500=104=20.8 \%$

Muzaffargarh: $\mathrm{nz}=(17,000 / 100,500) * 500=85=17 \%$

Dera Ghazi Khan: $\mathrm{nz}=(18,500 / 100,500) * 500=92=18.4 \%$

\begin{tabular}{|c|c|}
\hline 500 & $100 \%$ \\
\hline Baha & $00 / 100,500) * 500=72=14.4 \%$ \\
\hline
\end{tabular}

4.

Finally, 147 respondents were selected randomly form Bahawalpur, 104 from Rahim Yar Khan, 85 from Muzaffargarh, 92 from Dera Ghazi Khan and 72 from Bahawalnagar.

\subsection{Sample Size}

Regarding the sample size for this study is determined by using Krejcie and Morgan (56) table for sample size calculation. Total women participants in Southern Punjab is more than 100,000 . By following the recommendations of Krejcie and Morgan (56) if the population greater than 100,000, then the sample size should be not less than 384 . Thus, the sample size of this study is 500 female participants of microfinance institutes in Southern Punjab, Pakistan.

\subsection{Measurements}

WE is measured based on four indicators namely, family decision making, freedom of mobility, economic security and household economic decision making. Micro-credit is measured based on process, interest rate, amount (size), procedure and repayment period. Micro-saving measured based on interest rate, process, product options and need of saving. Micro-insurance measured based on benefits of insurance, variation in polices, installment and repayment. Finally, vulnerability is measured based on environmental factors, health factors, economic factors and political factors. All these measures were adapted from previous studies. 
5-point Likert scale was used to collect data from female clients of microfinance institutes. Instrument of the current study was adapted from previous studies such as WE was adapted from Sujatha Gangadhar and Malyadri (21) and Nawaz, Jahanian (57), micro-credit, micro-saving and micro-insurance was adapted from Bernard, Kevin (51) and vulnerability was adapted from Stewart (12). Survey questionnaire is given in appendix.

\section{Results}

The current study utilized Partial Least Square-Structural Equation Modeling (PLS-SEM) techniques to evaluate the data. Various prior studies recommended that it is most appropriate technique to analyze the primary data $(58,59)$. Henseler, Ringle $(59)$ recommended various steps of PLS-SEM as shown in Fig. 3.

[Insert Fig. 3 Here]

\subsection{Measurement Model Assessment}

By following the recommendations of prior studies, the individual item reliability was measured by considering the PLS outer loadings of each item of each construct (60-63). Thus, the factor loadings of all items were examined. According to Hair, Black (64), items having 0.4 -factor loading should be deleted. In the current study, all the items have factor loadings between 0.511 to 0.912 . To measure the internal consistency, the Cronbach's alpha (a) and composite reliability (CR) is used as it is mentioned by different prior studies (65-67). Both $a$ and CR coefficients are above 0.7 which is minimum threshold level in this study.

Moreover, convergent validity was achieved through average variance extracted (AVE). According to Fornell and Larcker (68), convergent validity requires equal or above 0.5 level of AVE. Therefore, to attain the convergent validity, the AVE must be above 0.5 as recommended by Chin (69). Additionally, Hair, Black (64) explained that the convergent validity is attained when the factor loadings of all the items of a construct are higher than 0.5 . Figure 4 shows the factor loadings and AVE value. Table 1 depicts the measurement model results. Furthermore, in the current study, discriminant validity was achieved by using the square root of AVE, as suggested by Fornell and Larcker (68). It is shown in Table 2. 
Table 1

Factor Loading, Alpha, CR and AVE

\begin{tabular}{|c|c|c|c|c|c|}
\hline Construct & Indicators & Loadings & $a$ & CR & AVE \\
\hline Micro-Credit (MC) & $\begin{array}{l}\text { MC1 } \\
\text { MC2 } \\
\text { MC4 }\end{array}$ & $\begin{array}{l}.810 \\
.745 \\
.829\end{array}$ & .717 & .837 & .633 \\
\hline Micro-Saving (MS) & $\begin{array}{l}\text { MS1 } \\
\text { MS2 } \\
\text { MS3 } \\
\text { MS4 }\end{array}$ & $\begin{array}{l}.797 \\
.813 \\
.810 \\
.807\end{array}$ & .821 & .882 & .650 \\
\hline Micro-Insurance (MI) & $\begin{array}{l}\text { Ml1 } \\
\text { Ml2 } \\
\text { Ml3 } \\
\text { Ml4 } \\
\text { Ml5 }\end{array}$ & $\begin{array}{l}.900 \\
.900 \\
.912 \\
.904 \\
.601\end{array}$ & .899 & .928 & .726 \\
\hline Vulnerability (VLNA) & $\begin{array}{l}\text { VLNA2 } \\
\text { VLNA6 } \\
\text { VLNA7 } \\
\text { VLNA8 } \\
\text { VLNA9 } \\
\text { VLNA10 } \\
\text { VLNA11 } \\
\text { VLNA12 } \\
\text { VLNA13 } \\
\text { VLNA14 } \\
\text { VLNA15 } \\
\text { VLNA16 } \\
\text { VLNA17 } \\
\text { VLNA18 } \\
\text { VLNA19 }\end{array}$ & $\begin{array}{l}.511 \\
.636 \\
.715 \\
.793 \\
.775 \\
.729 \\
.822 \\
.779 \\
.823 \\
.733 \\
.736 \\
.636 \\
.665 \\
.682 \\
.660\end{array}$ & .931 & .940 & .515 \\
\hline Women-Empowerment (WE) & $\begin{array}{l}\text { WE5 } \\
\text { WE6 } \\
\text { WE7 } \\
\text { WE8 } \\
\text { WE9 } \\
\text { WE10 } \\
\text { WE11 } \\
\text { WE12 } \\
\text { WE13 } \\
\text { WE14 } \\
\text { WE15 } \\
\text { WE16 } \\
\text { WE17 } \\
\text { WE18 } \\
\text { WE19 } \\
\text { WE20 } \\
\text { WE21 }\end{array}$ & $\begin{array}{l}.531 \\
.631 \\
.708 \\
.772 \\
.747 \\
.718 \\
.809 \\
.761 \\
.803 \\
.721 \\
.719 \\
.665 \\
.691 \\
.710 \\
.700 \\
.687 \\
.747\end{array}$ & .940 & .947 & .512 \\
\hline
\end{tabular}


Table 2

Discriminant Validity

\begin{tabular}{|c|c|c|c|c|c|}
\hline & MC & MI & MS & VLNA & WE \\
\hline$M C$ & 0.795 & & & & \\
\hline MI & 0.747 & 0.852 & & & \\
\hline MS & 0.489 & 0.480 & 0.807 & & \\
\hline VLNA & 0.633 & 0.662 & 0.613 & 0.718 & \\
\hline WE & 0.655 & 0.680 & 0.610 & 0.694 & 0.716 \\
\hline
\end{tabular}

[Insert Fig. 4 Here]

[Insert Table 1 Here]

[Insert Table 2 Here]

\subsection{Structural Model Assessment}

After examining the measurement model assessment, the study examined the structural model assessment (Fig. 5). In this direction, PLS bootstrapping was performed and 353 cases to determine the significance of the structural model. This procedure was followed by the instructions of various previous studies $(59-61,70)$.

[Insert Fig. 5 Here]

[Insert Table 3 Here]

Table 3

Structural Model Results

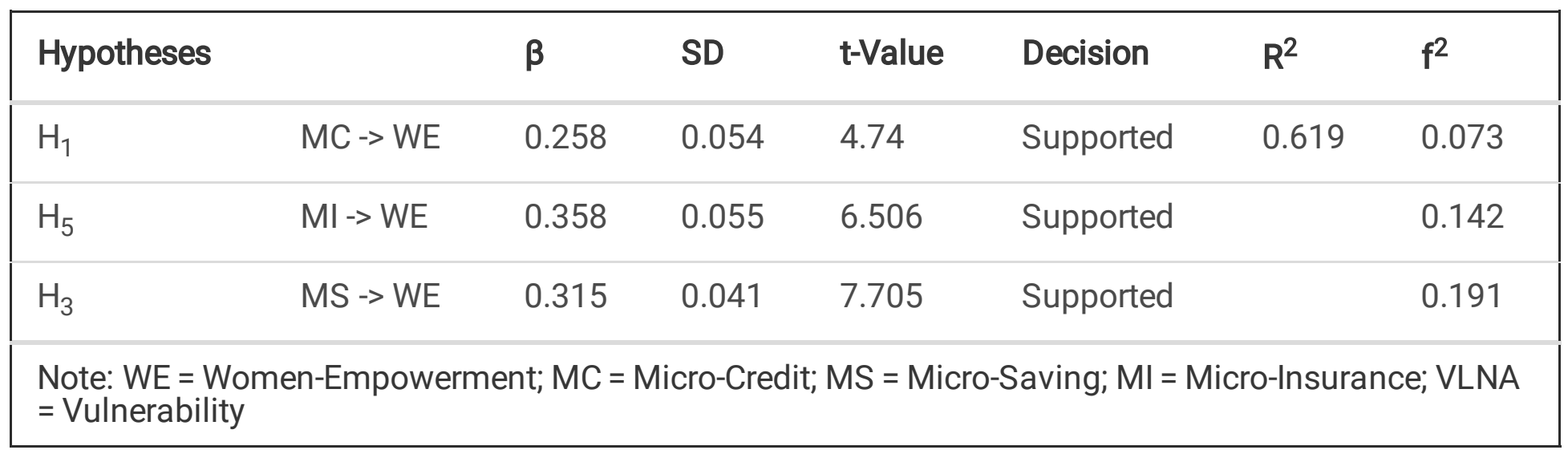


Table 3 depicts the outcomes of hypotheses testing. According to these results, micro-credit and WE shows significant positive relationship $(\beta=0.258, t=4.74)$. The relationship between micro-saving and WE also found positive and significant $(\beta=0.315, t=7.705)$. In line with these results, relationship between micro-insurance and WE was found significant positive $(\beta=0.358, t=6.506)$. Thus, these results supported $\mathrm{H} 1, \mathrm{H} 3$ and $\mathrm{H} 5$. In case of moderation effect of vulnerability, Fig. 6 shows the moderation effect and Table 4 exhibits the results of moderation effect. The moderation effect of vulnerability between micro-credit and WE found significant $(\beta=-0.023, t=2.775)$. The moderation effect of vulnerability between micro-saving and WE found significant $(\beta=0.023, t=3.452)$. However, the moderation effect between micro-insurance and WE found insignificant $(\beta=0.009, t=1.052)$.

Table 4

Moderation Results

\begin{tabular}{|lllllll|}
\hline & Std. beta & Std. Error & t-Value & L.L & U. L & Decision \\
\hline MC* VLNA-> WE & -0.023 & 0.008 & 2.775 & 0.038 & 0.007 & Supported \\
\hline MS* VLNA-> WE & 0.023 & 0.007 & 3.452 & 0.010 & 0.036 & Supported \\
\hline MI* VLNA-> WE & 0.009 & 0.009 & 1.052 & -0.005 & 0.028 & Not Supported \\
\hline $\begin{array}{l}\text { Note: WE = Women-Empowerment; } \text { MC = Micro-Credit; MS = Micro-Saving; Ml = Micro-Insurance; VLNA } \\
\text { = Vulnerability }\end{array}$
\end{tabular}

[Insert Fig. 6 Here]

[Insert Table 4 Here]

In Fig. 5 and Table 4, it is evident that vulnerability moderation the relationship in case of micro-credit and micro-insurance. However, Figs. 7 and 8 shows the direction of moderation effect. Figure 6 shows that vulnerability is a moderating variable which decreases the positive relationship between micro-credit and WE. On the other hand, Fig. 7 shows that vulnerability is a moderating variable which increases the positive relationship between micro-credit and WE. Thus, vulnerability weaken the relationship of microcredit and WE. It strengthens the relationship between micro-saving and WE.

[Insert Fig. 7 Here]

[Insert Fig. 8 Here]

In the final part of analysis, Table 5 demonstrates the predictive relevance $\left(Q^{2}\right)$. Chin (69) demonstrates that the predictive relevance $\left(Q^{2}\right)$ is a standard to examine how well a model forecasts the data of various omitted cases. Additionally, it is described that $\mathrm{Q}^{2}$ value is attained by using the blindfolding "to assess the parameter estimates" and also assess "how values are built around the model". The $\mathrm{Q}^{2}$ clarifies the quality of the overall model. According to the Henseler, Ringle (59), in a research model, if the value of $Q^{2}$ is higher than zero, it is supposed that the model has a sufficient level of $Q^{2}$. 
Table 5

Predictive relevance $\left(\mathrm{Q}^{2}\right)$

\begin{tabular}{|c|c|c|c|}
\hline & sso & SSE & $\mathrm{Q}^{2}(=1-\mathrm{SSE} / \mathrm{SSO})$ \\
\hline WE & $6,001.00$ & $3,175.61$ & 0.471 \\
\hline
\end{tabular}

[Insert Table 5 Here]

Additionally, effect size $\left(\mathrm{f}^{2}\right)$ is shown in Table 3. Cohen (71) recommended the different values of $\mathrm{f}^{2}$, according to these values, 0.02 is considered a small $f^{2}, 0.15$ considered as moderate $f^{2}$ and 0.35 is considered a strong $\mathrm{f}^{2}$. In the current study, micro-credit has small f2 (0.073), micro-saving has moderate $f^{2}(0.191)$ and micro-insurance also has small $f^{2}(0.142)$. Finally, the r-square $\left(R^{2}\right)$ value in the current study is 0.619 which is substantial accounting to the recommendations of Chin (69). It is shown in Table 3. It demonstrates that all the exogenous latent variables are expected to bring $61.9 \%$ change in endogenous latent variable.

\section{Discussion}

The current study carried out to observe the role of vulnerability and microfinance institutes in WE. The role environmental, health, economic and political vulnerability was also examined. Primary data were analyzed with the help of PLS-SEM. Results of the study revealed that microfinance institutes are most significant to enhances WE. Services of microfinance such as micro-credit, micro-saving and microinsurance has significant positive relationship with WE. Provision of these services has the ability to decreases poverty among women and increases their social and economic well-beings. Financial capital (micro-credit, micro-saving, micro-insurance) from microfinance institutes make them capable to run their businesses which increases the income and decision-making power of women. However, vulnerability decreases the positive effect of micro-credit towards WE. Vulnerability act like a limiting factor which weaken the positive relationship of micro-credit and WE.

The outcomes of this study are steady with prior studies. Nader (72) conducted a research study on microcredit as well as the socio-economic welfare of women in Cairo. The author found that micro-credit is significant element which enhances the women socio-economic well-being. According to Nader (72), credit is most important to reduce poverty and has a positive association with women's social and economic welfare. Micro-credit has the ability to increases the socio-economic empowerment of females by reducing the poverty level (16). Because it significantly advances the income and women decisionmaking power (25). Thus, with the increase in income, it also enhances the social empowerment among the female community. When women get a loan from microfinance institutes, they decide to utilize it which creates social empowerment. It also allows females to take part in decision-making related to the household matters. 
Most of the previous studies also have the same findings. Ashraf, Karlan (52) conducted a research study on savings products in the Philippines. The author found that savings enhance the empowerment through an increase in decision-making inside the house. Increase in decision making power increases the social empowerment among the female community. Moreover, Bernard, Kevin (51) found that saving has a significant as well as positive connection with women micro-enterprise success. Increase in micro enterprise success generates income which enhances women economic empowerment.

A study conducted on micro-insurance, WE and self-help groups by Amudha, Selvabaskar (73) in Tiruchirappalli, indicates that micro-insurance improves the socio-economic empowerment by providing shelter to prevent from the hazards of low-income individuals in exchange of a premium. Another study led in India by Rajeswari (74) on the role of insurance corporation in WE found a positive association between insurance and WE. Furthermore, micro-insurance is one of the mechanisms of social security, and it also elevates the living standard of poor people (75). Therefore, it has a positive influence on WE by decreasing poverty level (76). Thus, these studies are in line with the results of the current study. However, again, Atmadja, Su (45) are inconstant with the conclusions of the current study.

However, results of the study demonstrated that vulnerability elements such as environmental, health, economic/social and political has negative influence in case of micro-credit. Because the women get loan from microfinance institutes, invest in micro-enterprise, but their micro-enterprises destroy due to vulnerability and they face the repayment issues of loan. In this case, women sell their assets to repay the loan which drag them towards more poverty. As mentioned by Herath, Guneratne (77) vulnerability reduces WE. Increases in vulnerability factors such as environmental, health, economic and political will decreases the WE.

\section{Conclusions}

There are various factors which effect on women-empowerment among developing countries. However, the most important are vulnerability factors such as women health vulnerability, environment vulnerability, economic/social vulnerability and political vulnerability should be managed to increase women-empowerment. These vulnerability factors drag poor women towards deeper poverty by destroying their business activities and decision-making power. Microfinance institutes is one of the solutions to handle these vulnerabilities through various services. Various services of microfinance institutes such as micro-credit, micro-savings and micro-insurance has the ability to empower women community. Therefore, the current study is significant for microfinance institutes, state bank of Pakistan and government of Pakistan while making the strategies to enhance women-empowerment.

Implications of the Study

This study has more importance for microfinance institutes. As the fundamental objective of microfinance institutes is to diminish the poverty and enhance $W E$, therefore, microfinance institutes could take help from this study to improve WE. Thus, this study revealed that why microfinance institutes are still not able to empower women in Southern Punjab Pakistan even the hundreds of microfinance 
institutes are working in this area. The reason is that vulnerability factors destroy the women micro enterprise which effects negatively. Therefore, this study is a major importance for microfinance institutes, particularly those microfinance institutes which are working in Southern Punjab, Pakistan. This study is also important for the Government of Pakistan and State Bank of Pakistan (SBP) to get clues while making the strategy for WE. As this study revealed important points to enhance WE. This study is also important for Government of Pakistan and State Bank of Pakistan because it highlights various reasons that why WE is not yet achieved in Southern Punjab, Pakistan, even hundreds of branches of microfinance institutes are working form many decades in this region. Thus, in future government of Pakistan can make better strategies to enhances WE by reducing the vulnerability issues.

\section{Abbreviations}

WE

Women-Empowerment; MC = Micro-Credit; MS = Micro-Saving; MI = Micro-Insurance; VLNA = Vulnerability

\section{Declarations}

Ethical Statement:

An ethical statement is not applicable.

Ethics approval and consent to participate

The data collection was carried out after getting approval from the microfinance institutions and ethical committee of Pakistan microfinance review. An official permission was obtained from the microfinance institutions administrative office. All of the study participants were 18 years and above, and data collection was carried out after written consent was obtained from study participants. Confidentiality of the information was assured from all the data collectors and investigators sides. The names and address of the participants was not recorded in the questionnaire.

Competing Interest:

The authors declare no conflict of interest.

Funding:

This research received no external funding.

Author Contributions

The author fully contributed to the article.

Acknowledgments

We would like to acknowledge Hisham Bin Mohammad, Hanita Binti Kadir Shahar and Shazma Razzaq to give us the valuable instructions and make us capable to produce good research.

\section{References}

1. Nasir S, Farooqi S, Akhtar. Impact of Microfinance on Women Empowerment with Special Reference to District Aligarh (India). Middle-East Journal of Scientific Research. 2016;24(3):491-7. 
2. Hameed, Nisar QA, Abbas A, Waqas A, Meo S, Muhammad. Microfinance Institutions as a Strategic Tool to Enhance Women's Career Development in Pakistan. Asian Women. 2019;35(2).

3. Das S, Singh P. Rural Women Empowerment and its Relationship with Economic Development: A Study of Cachar District of the State Assam. IASSI Quarterly. 2019;38(2).

4. Ernest, Young. A powerful untapped economic force for the continent [African economic survey]. Global entrepreneurship monitor in Africa. 2010.

5. Evbuomwan GO, Ikpi A, Okoruwa V, Akinyosoye V. Preferences of micro, small and medium scale enterprises to financial products in Nigeria. Journal of Agricultural Economics and Development. 2012;14:80-98.

6. Norizaton N, M, Abdul Halim H, Chong C, W. Factors affecting profitabilitity of women entrepreneurs business in Malaysia. Annual Summit on Business and Entrepreneurial Studies (ASBES 2011) Proceeding. 2011.

7. Ul-Hameed W, Mohammad H, Shahar H. Microfinance institute's non-financial services and womenempowerment: The role of vulnerability. Management Science Letters. 2018;8(10):1103-16.

8. Yasmeen K. The impact of microfinance loan on women's empowerment and happiness in Pakistan: Universiti Utara Malaysia; 2015.

9. Schnitter R, Verret M, Berry P, Chung Tiam Fook T, Hales S, Lal A, et al. An assessment of climate change and health vulnerability and adaptation in Dominica. International journal of environmental research and public health. 2019;16(1):70.

10. Ahmed I, Ayeb-Karlsson S, van der Geest K, Huq S, Jordan JC. Climate change, environmental stress and loss of livelihoods can push people towards illegal activities: a case study from coastal Bangladesh. Climate and Development. 2019:1-11.

11. Ruiz Estrada MA, Park D, Moug P. A New Assessment to Measure the Risk Levels Between Natural Disasters and Socio-Economic-Political Disasters. Available at SSRN 3400582. 2019.

12. Stewart RM. Community perspectives of flood risk and social vulnerability reduction: the case of the Red River Basin. 2007.

13. Ahlawat S. Financial Performance of Group Based Microfinance Model in Haryana. Integrated Journal of Social Sciences. 2016;3(1):9-12.

14. Al-Shami SSA, Razali MM, Majid I, Rozelan A, Rashid N. The effect of microfinance on women's empowerment: Evidence from Malaysia. Asian Journal of Women's Studies. 2016;22(3):318-37.

15. Al-shami SSA, Razali R, Rashid N. The effect of microcredit on women empowerment in welfare and decisions making in Malaysia. Social Indicators Research. 2018;137(3):1073-90.

16. Kodamarty M, Srinivasan R. Microfinance and Women Empowerment: Evidence from India - Review of Literature. . Indian Journal Of Applied Research. 2016;6(2):711-3. .

17. Garikipati S. The impact of lending to women on household vulnerability and women's empowerment: evidence from India. World Development. 2008;36(12):2620-42. 
18. Garikipati S. The Impact of Microfinance on Poverty Alleviation: Making Sense of the Evidence. Development Finance: Springer; 2017. p. 189-206.

19. Ghalib AK, Malki I, Imai KS. Microfinance and household poverty reduction: Empirical evidence from rural Pakistan. Oxford Development Studies. 2015;43(1):84-104.

20. Roy A. Inclusive Growth through MFIs' Outreach in Assam. Asia Pacific Business Review. 2011;7(3):47-62.

21. Sujatha Gangadhar C, Malyadri P. Impact of Microfinance on Women Empowerment: An Empirical Evidence from Andhra Pradesh. J Entrepren Organiz Manag. 2015;4:141.

22. Review PM. Pakistan Microfinance Review 2017. Annual assessment of the industry. . Pakistan Microfinance Network http://microfinanceconnectinfo/assets/articles/da6af2f0f19ca541bbc04db2f158cf98pdf. 2017:192.

23. Banerjee SB, Jackson L. Microfinance and the business of poverty reduction: Critical perspectives from rural Bangladesh. human relations. 2017;70(1):63-91.

24. Afzal M, Rafique S, Hameed F. Measurement of living standards deprivation in Punjab using AF method (periodical comparison approach). The Pakistan Development Review. 2015;54(4 Partl \&):739-63.

25. Kapila M, Singla A, Gupta M, editors. Impact of Microcredit on Women Empowerment in India: An Empirical Study of Punjab State. Proceedings of the World Congress on Engineering; 2016.

26. Jamal MA, Raihana AKA, Sultana HY. Empowerment of Muslim Women through Microfinance and Self Help Groups: A Case Study of Chennai City. Asian Business Review. 2016;6(2):117-24.

27. Leach F, Sitaram. Development in Practice Microfinance and women 's India Microfinance and women 's empowerment : a lesson from India. Development in Practice, (January 2012), . 2010:3741.

28. Phillips BD, Fordham M. Introduction”, in Phillips, B.D., Thomas, D.S.K., Fothergill, A. and Blinn-Pike, L. (Eds), Social Vulnerability to Disasters, . CRC Press, Boca Raton, FL. 2010:1-26.

29. Wisner B, Blaikie P, Cannon T, Davis I. At risk. Natural hazards, people's vulnerability and disasters. 2004;2:471.

30. Christiaensen LJ, Subbarao K. Towards an understanding of household vulnerability in rural Kenya. Journal of African Economies. 2005;14(4):520-58.

31. Zhang Y, Wan G. An empirical analysis of household vulnerability in rural China. Journal of the Asia Pacific Economy. 2006;11(2):196-212.

32. Adger WN. Vulnerability. Global environmental change. 2006;16(3):268-81.

33. Wilson G. Community resilience and environmental transitions: Routledge; 2012.

34. Bali Swain R, Floro M. Microfinance, vulnerability and risk in low income households. International review of applied economics. 2014;28(5):539-61. 
35. Narayan D, Pritchett L. Cents and sociability: Household income and social capital in rural Tanzania. Economic development and cultural change. 1999;47(4):871-97.

36. Birkmann J. Measuring vulnerability to promote disaster-resilient societies: Conceptual frameworks and definitions. Measuring vulnerability to natural hazards: Towards disaster resilient societies. 2006;1:9-54.

37. McEntire D, Gilmore Crocker MPH C, Peters E. Addressing vulnerability through an integrated approach. International Journal of Disaster Resilience in the Built Environment. 2010;1 (1):50-64.

38. Mayoux L. Participatory Learning for Women's Empowerment in Micro-Finance Programmes: Negotiating Complexity, Conflict and Change. IDS bulletin. 1998;29(4):39-50.

39. Mayoux L. Women's Empowerment through Sustainable Microfinance. Rethinking Best. 2005.

40. Mayoux L, editor Sustainable micro-finance for women's empowerment. A Report of the International Mutual Learning Workshop; 2006.

41. Boholm Å, Corvellec H. A relational theory of risk. Journal of risk research. 2011;14(2):175-90.

42. Kessy J, Msuya S, Mushi D, Stray-Pedersen B, Botten G. Integration of microfinance institutions and health programs in northern Tanzania. PARIPEX-Indian Journal of Research. 2016;5(1).

43. Asiama JP, Osei V. Microfinance in Ghana: an overview. Accra, Ghana: Research Department, Bank of Ghana. 2007.

44. Zoynul AM, Fahmida M. WOMEN EMPOWERMENT THROUGH MICRO CREDIT: A CASE STUDY OF DINAJPUR, BANGLADESH. Studies in Business \& Economics. 2013;8(2).

45. Atmadja AS, Su J-J, Sharma P. Examining the impact of microfinance on microenterprise performance (implications for women-owned microenterprises in Indonesia). International Journal of Social Economics. 2016;43(10):962-81.

46. Garikipati S. Microcredit and women's empowerment: Have we been looking at the wrong indicators? Oxford Development Studies. 2013;41(sup1):S53-S75.

47. Ashraf N, Karlan D, Yin W. Tying Odysseus to the mast: Evidence from a commitment savings product in the Philippines. The Quarterly Journal of Economics. 2006;121(2):635-72.

48. Mkpado $M$, Arene $C$. Effects of democratization of group administration on the sustainability of agricultural micro credit groups in Nigeria. International Journal of Rural Studies. 2007;14(2).

49. Knowles J. Increasing the Productivity and Earnings of Rural Women: What Works? A Roadmap for Promoting Women's Economic Empowerment Available at: www womeneconroadmap org Accessed November. 2013.

50. Dupas P, Robinson J. Savings constraints and microenterprise development: Evidence from a field experiment in Kenya. American Economic Journal: Applied Economics. 2013;5(1):163-92.

51. Bernard DK, Kevin LLT, Khin AA. Entrepreneurial success through microfinance services among women entrepreneurs in Sri Lanka: A pilot study and overview of the findings. International Journal of Economics and Financial Issues. 2016;6(3):1144-50. 
52. Ashraf N, Karlan D, Yin W. Female empowerment: Impact of a commitment savings product in the Philippines. World development. 2010;38(3):333-44.

53. Churchill LJ. Is There a Woman in This Textbook? Feminist Pedagogy and Elementary Latin. When Dead Tongues Speak: Teaching Beginning Greek and Latin. 2006:86-109.

54. Najmi HS, Bashir D, Zia M. Socioeconomic Impact of Microfinance on Borrowers: A Case Study of NRSP Bank Minchanabad. 2015.

55. Cohen M, McCord MJ, Sebstad J. Reducing vulnerability: Demand for and supply of microinsurance in East Africa. Journal of International Development: The Journal of the Development Studies Association. 2005;17(3):319-25.

56. Krejcie RV, Morgan DW. Determining sample size for research activities. Educational and psychological measurement. 1970;30(3):607-10.

57. Nawaz N, Jahanian A, Manzoor S. Empowering women through microcredit: A case study of Tameer microfinance bank, Bahawalpur. Journal of Economics and Sustainable Development. 2012;3(6):1721.

58. Reinartz W, Haenlein M, Henseler J. An empirical comparison of the efficacy of covariance-based and variance-based SEM. International Journal of research in Marketing. 2009;26(4):332-44.

59. Henseler J, Ringle CM, Sinkovics RR. The use of partial least squares path modeling in international marketing. New challenges to international marketing: Emerald Group Publishing Limited; 2009. p. 277-319.

60. F. Hair Jr J, Sarstedt M, Hopkins L, G. Kuppelwieser V. Partial least squares structural equation modeling (PLS-SEM) An emerging tool in business research. European Business Review. 2014;26(2):106-21.

61. Hair JF, Sarstedt M, Pieper TM, Ringle CM. The use of partial least squares structural equation modeling in strategic management research: a review of past practices and recommendations for future applications. Long range planning. 2012;45(5-6):320-40.

62. Duarte PAO, Raposo MLB. A PLS model to study brand preference: An application to the mobile phone market. Handbook of partial least squares: Springer; 2010. p. 449-85.

63. Hulland J. Use of partial least squares (PLS) in strategic management research: A review of four recent studies. Strategic management journal. 1999;20(2):195-204.

64. Hair JF, Black WC, Babin BJ, Anderson RE, Tatham R. Multivariate Data Analysis (ed.): Pearson Prentice Hall. 2010.

65. Bacon DR, Sauer PL, Young M. Composite reliability in structural equations modeling. Educational and Psychological Measurement. 1995;55(3):394-406.

66. McCrae RR, Kurtz JE, Yamagata S, Terracciano A. Internal consistency, retest reliability, and their implications for personality scale validity. Personality and social psychology review. 2011;15(1):2850 . 
67. Peterson RA, Kim Y. On the relationship between coefficient alpha and composite reliability. Journal of Applied Psychology. 2013;98(1):194.

68. Fornell C, Larcker DF. Evaluating structural equation models with unobservable variables and measurement error. Journal of marketing research. 1981:39-50.

69. Chin WW. The partial least squares approach to structural equation modeling. Modern methods for business research. 1998;295(2):295-336.

70. Hair JF, Ringle CM, Sarstedt M. PLS-SEM: Indeed a silver bullet. Journal of Marketing theory and Practice. 2011;19(2):139-52.

71. Cohen J. Statistical power analysis for the behavioral sciences. 2nd. Hillsdale, NJ: erlbaum; 1988.

72. Nader YF. Microcredit and the socio-economic wellbeing of women and their families in Cairo. The Journal of Socio-Economics. 2008;37(2):644-56.

73. Amudha R, Selvabaskar S, Motha LCS, editors. Micro-insurance: A mechanism for women empowerment through self help group linked LIC. Science Engineering and Management Research (ICSEMR), 2014 International Conference on; 2014: IEEE.

74. Rajeswari K. Role of life insurance corporation of India in women empowerment with reference to women agents. 2012.

75. Kishor NR, Prahalad C, Loster T. Micro insurance in India-Protecting the poor. Journal of Business Management and Social Sciences Research. 2013;2(3):39-44.

76. Rao KS. Micro Finance to the Poor: A Tool for Poverty Alleviation and Women Empowerment. MANAGEMENT ACCOUNTANT-CALCUTTA-. 2008;43(2):86.

77. Herath $\mathrm{H}$, Guneratne L, Sanderatne N. Impact of microfinance on women's empowerment: a case study on two microfinance institutions in Sri Lanka. Sri Lanka Journal of Social Sciences. 2015;38(1):51-61.

\section{Figures}




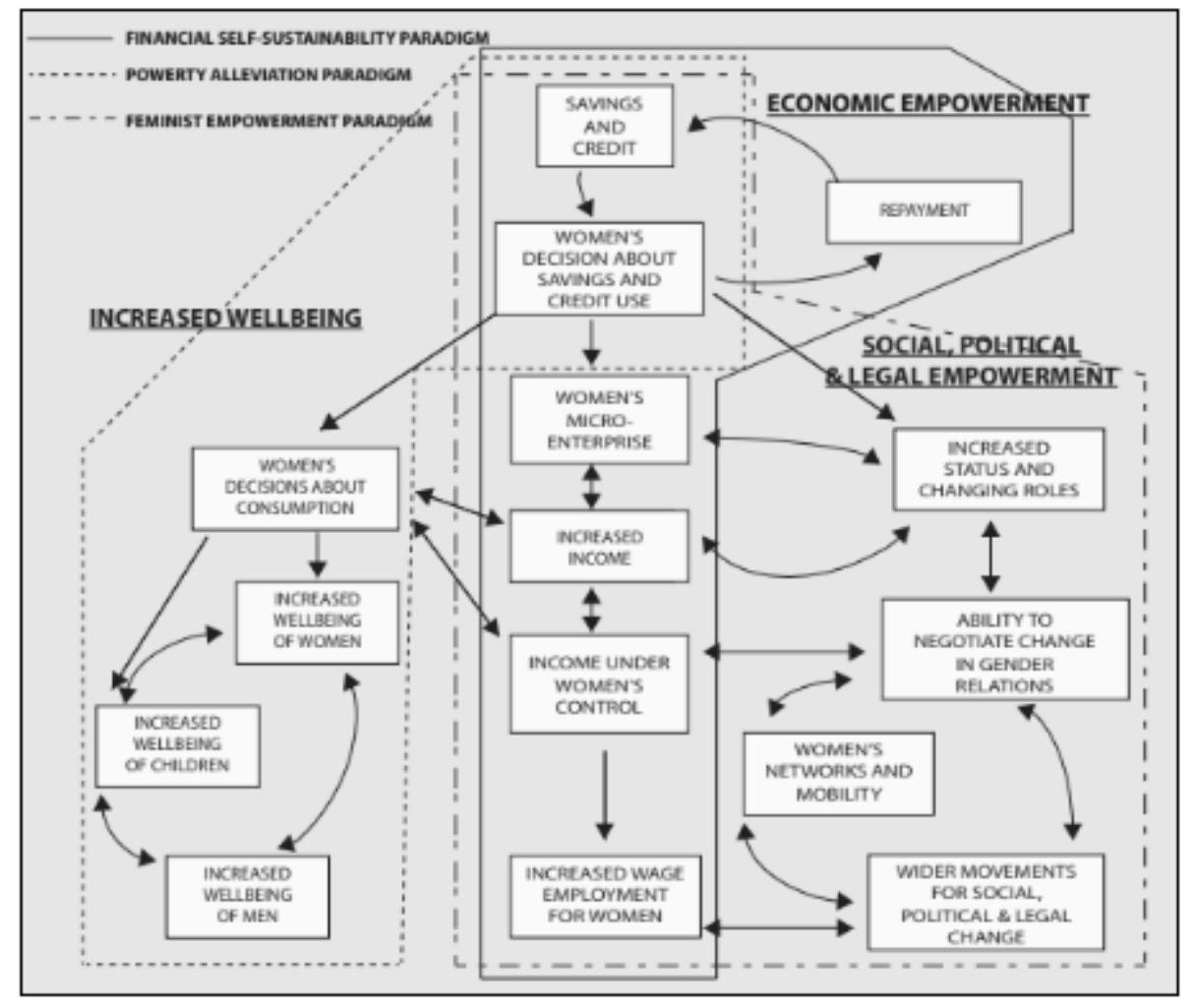

Figure 1

Mayoux's Feminist Empowerment Theory linking the WE with various microfinance

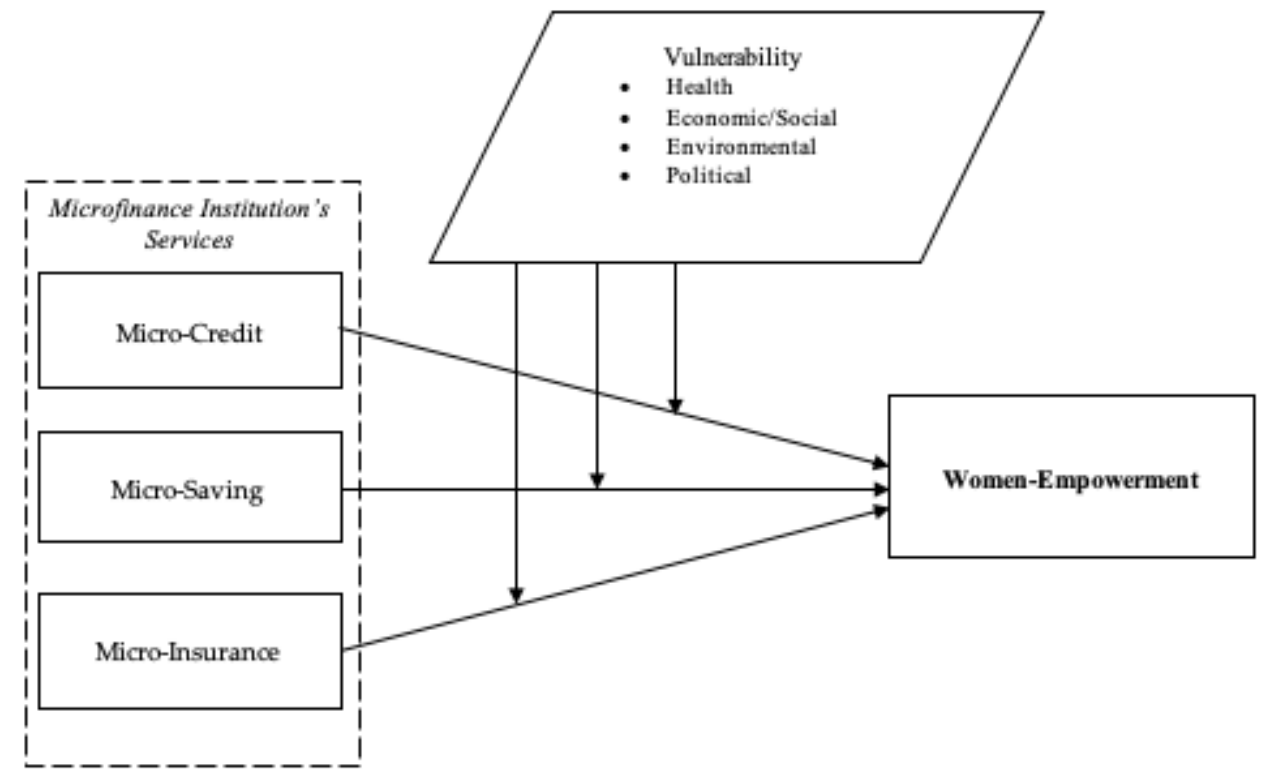

\section{Figure 2}

Theoretical framework of the study showing the relationship between health vulnerability, environmental vulnerability, economic/social vulnerability, political vulnerability, microfinance institutions and women- 
empowerment

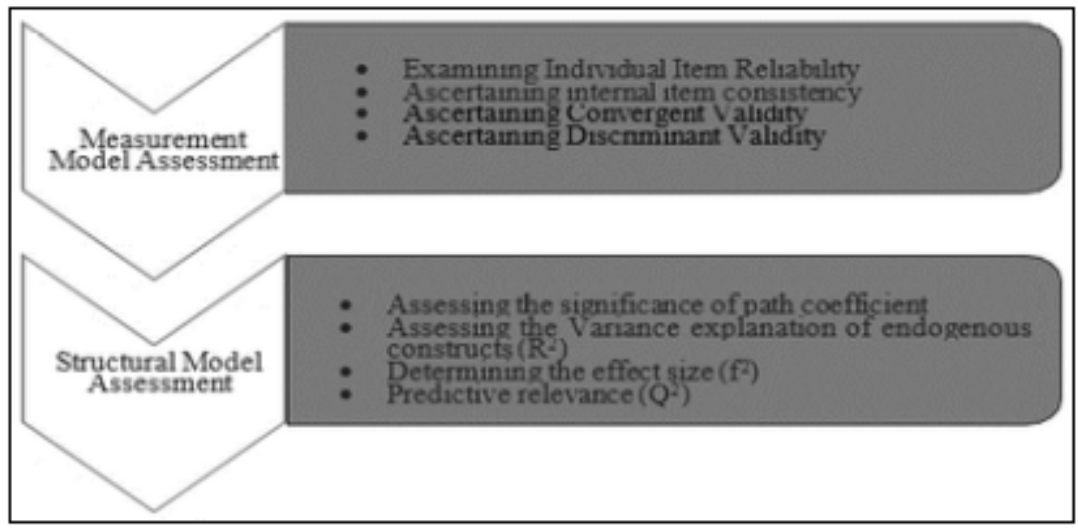

\section{Figure 3}

\section{PLS-SEM Steps}

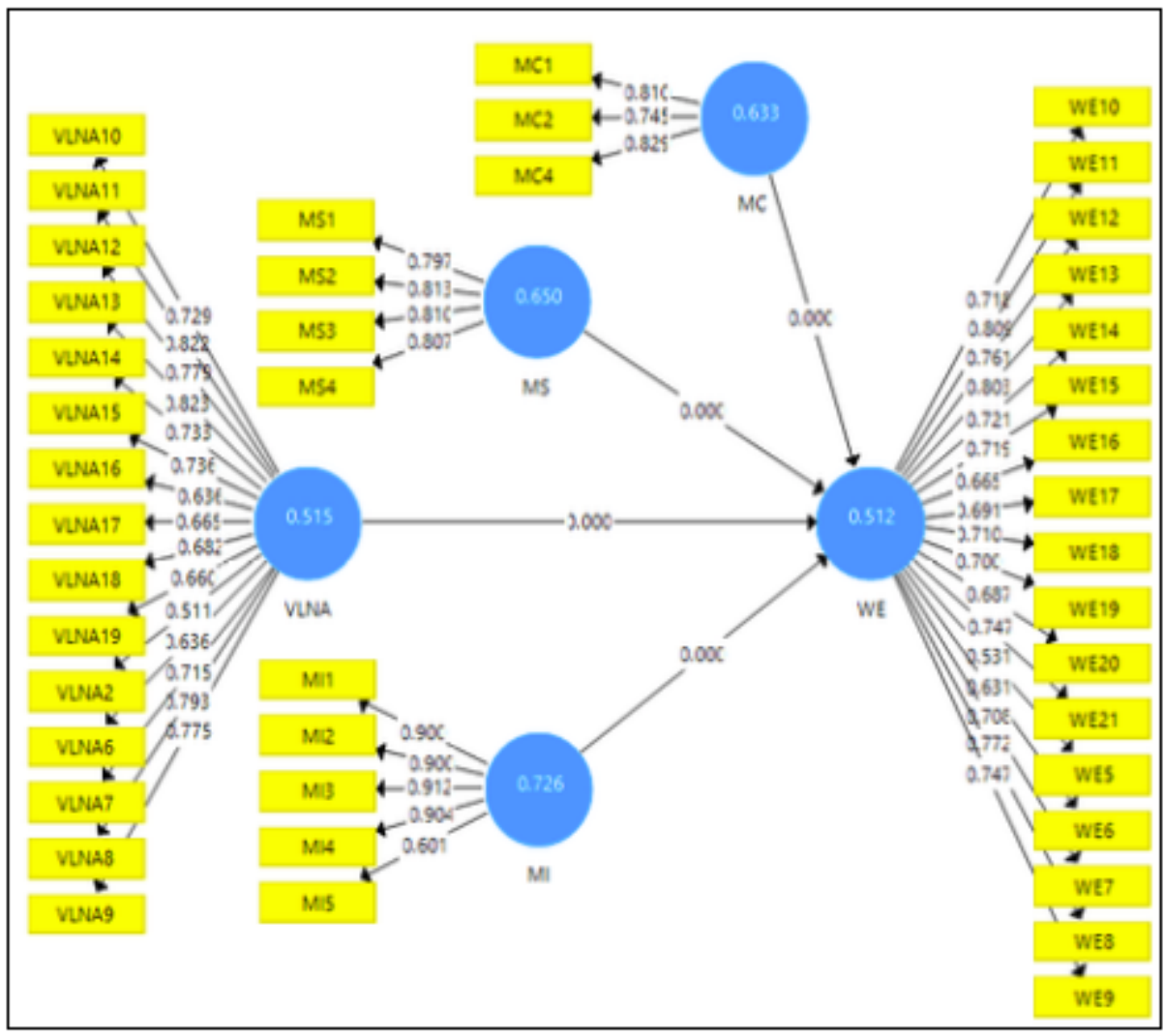

Figure 4

Confirmatory Factor Analysis (CFA) 


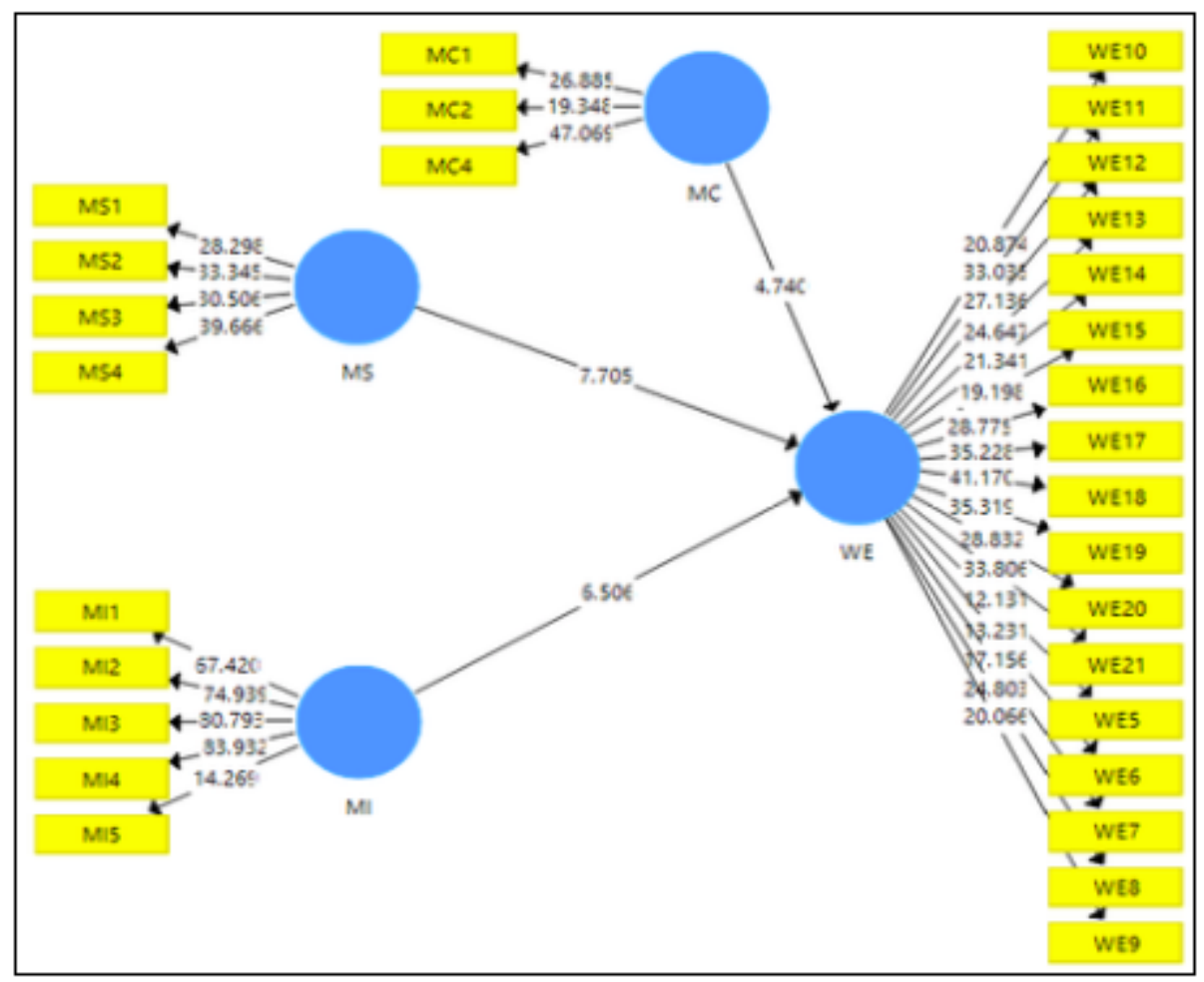

Figure 5

Structural Model Assessment

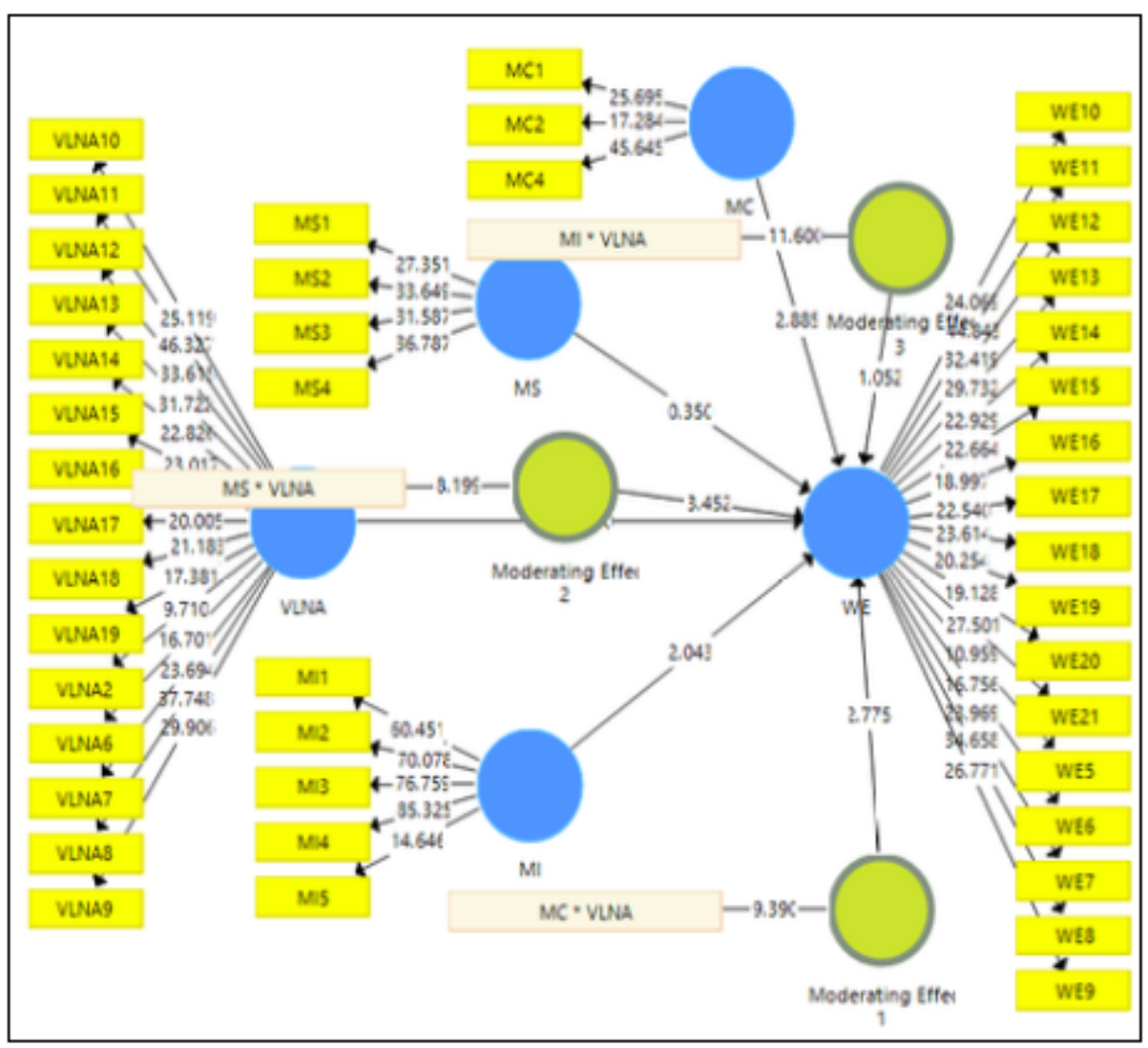

Figure 6 
Structural Model Assessment (Moderation Effect)

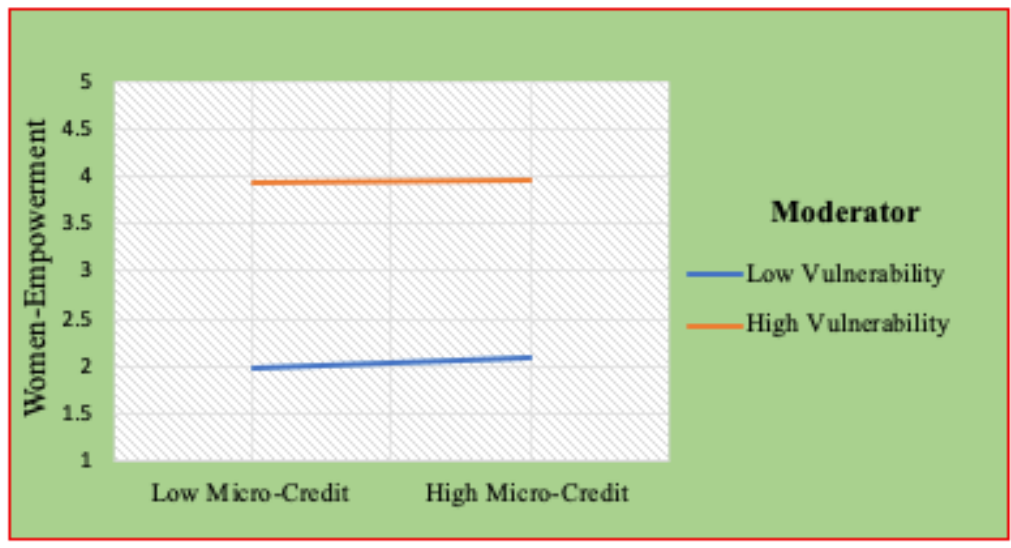

\section{Figure 7}

Moderation effect of vulnerability between micro-credit and WE

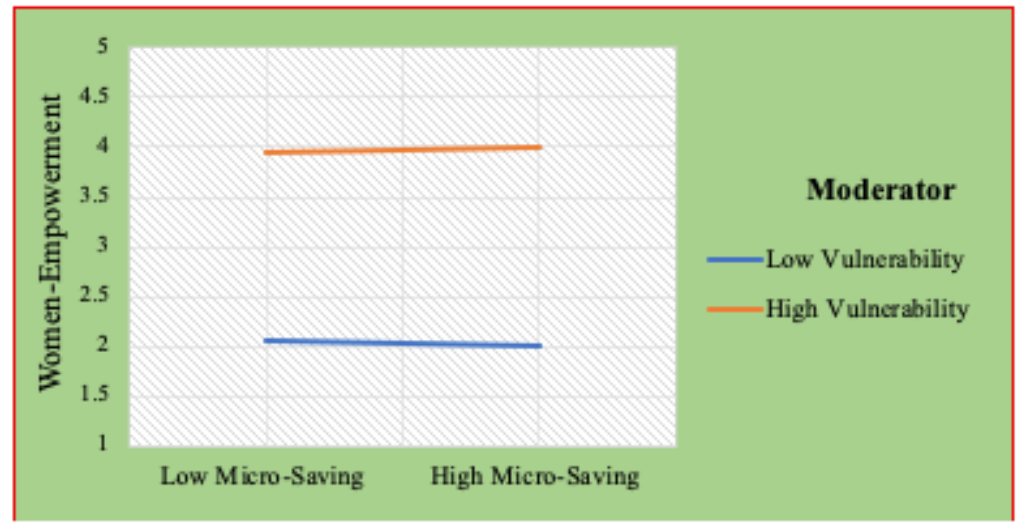

\section{Figure 8}

Moderation effect of vulnerability between micro-saving and WE 